\title{
APLIKASI JENJANG SOSIAL PENDATAAN KARTU KELUARGA BERBASIS WEB
}

\author{
Martono ${ }^{1}$ \\ Kartika $^{2}$ \\ Putri Aullia ${ }^{3}$ \\ Dosen Jurusan Teknik Informatika AMIK Raharja Informatika ${ }^{1}$, Alumni STMIK Raharja Jurusan \\ Sistem Informasi ${ }^{2}$, Mahasiswa STMIK Raharja Jurusan Sistem Informasi ${ }^{3}$ \\ Email:martono@raharja.info,tika_kartika@gmail.com,putri.aullia@raharja.info
}

Diterima: 8 Juni 2017/ Disetujui : 15 Juni 2017

\begin{abstract}
The technological advances in the world of information is growing very fast and demanding to stay one step ahead and follow the development of existing ones. We must strive to make innovations in the era of competition is growing rapidly. With all the advantages that exist on the computer is very important for companies or government agencies and the private sector who want to develop and use the power of technology to improve performance. In conducting the data processing activities in order to obtain optimal results. With tersajinya information quickly will speed up the decision-making process, so as to take advantage of the cost, time and energy more effectively and efficiently. In the village of Karang Anyar family card collection system is less accurate and there is a delay of data information. In the family card collection that became the problem is still a lot of people or applicants who still do not understand how the procedure or what is the procedure to be followed by a family card holders. Family card manufacturing process only takes place in the village environment only. Social Study Data Collection Application Family Card is a Web-based application program used to display information about family card data on coral village later and also can facilitate citizens make family cards quickly and accurately.
\end{abstract}

Keywords: Family Card, Application, Data Population.

\begin{abstract}
ABSTRAK
Kemajuan teknologi di dunia informasi mengalami pertumbuhan yang sangat cepat dan menuntut untuk selalu selangkah lebih maju dan mengikuti perkembangan yang telah ada. Kita harus berupaya untuk melakukan inovasi dalam era persaingan yang semakin pesat saat ini. Dengan segala kelebihan yang ada pada komputer sangat berperan penting bagi perusahaan atau instansi pemerintah dan swasta yang inginmengembangkan dan menggunakan kecanggihan teknologi untuk meningkatkan kinerjanya. Dalam melakukan aktivitas pemrosesan data sehingga diperoleh hasil yang optimal. Dengan tersajinya informasi yang cepat maka akan mempercepat proses pengambilan keputusan, sehingga dapat memanfaatkan biaya, tenaga dan waktu yang lebih efektif dan efisien. Pada Kelurahan Karang Anyar sistem pendataan kartu keluarga masih kurang akurat dan terjadi keterlambatan data informasi. Dalam pendataan kartu keluarga yang menjadi kendalanya adalah masih banyak orang atau pendaftar yang masih belum mengerti bagaimana tata cara atau bagaimana prosedur yang harus diikuti oleh seorang pemegang kartu keluarga. Proses pembuatan kartu keluarga hanya berlangsung di dalam lingkungan kelurahan saja. Aplikasi Jenjang Sosial Pendataan Kartu Keluarga berbasis Web adalah program aplikasi yang digunakan untuk menampilkan informasi tentang data kartu keluarga pada kelurahan karang anyar dan juga bisa memudahkan warga membuat kartu keluarga dengan cepat dan akurat.
\end{abstract}

Kata Kunci : Kartu Keluarga, Aplikasi, Data Penduduk. 


\section{PENDAHULUAN}

Di era globalisasi dan modernisasi ini komputer merupakan alat yang mempunyai banyak fungsi dalam berbagai bidang diantaranya bidang industri, pendidikan, pemerintahan, perdagangan, dan lain sebagainya. Komputer yang terdiri dari tiga komponen yang saling terkait antar lain Perangkat keras (hardware), perangkat lunak (software) serta manusia (brainware). Komponen-komponen ini saling berkaitan dalam mengolah data menjadi sebuah informasi yang berguna. Informasi ini yang berasal dari pengolahan komputer ini dapat digunakan sebagai bahan dasar pengambilan keputusan, agar keputusan yang dipilih dapat dipertanggung jawabkan dan menjadi terarah.

Kelurahan Karang Anyar adalah kelurahan yang terletak di Jl. Nyi Mas Melati No. 01 Rt. 002/02. Kecamatan Neglasari provinsi Banten dengan kode pos 15121, memiliki luas wilayah 153 Ha. Pada awal berdirinya Kelurahan Karang Anyar kantor kelurahan sempat berpindah lokasi, namun pada tahun 2009 berdasarkan permohonan untuk penempatan kantor Kelurahan Karang Anyar, maka bangunlah kantor Kelurahan Karang Anyar di salah satu lahan dari PT. Angkasa Pura II dengan luas $700 \mathrm{~m}$ yang di bangun dengan bantuan Pemerintah Kota Tangerang dan dana swadaya dari masyarakat setempat. Data kependudukan yang diperoleh bulan September 2012 tercatat bahwa jumlah penduduk Kelurahan Karang Anyar, yaitu17.558 jiwa dengan jumlah kepala keluarga 5.168 KK. Kekurangan sistem yang berjalan pada Kelurahan Karang Anyar saat ini adalah pendatan kartu keluarga, dimana proses pendataan kartu keluarga ini masih dilakukan secara manual. Dalam pendataan kartu keluarga yang menjadi kendalanya adalah masih banyak orang atau pendaftar yang masih belum mengerti bagaimana tata cara atau bagaimana prosedur yang harus diikuti oleh seorang pemegang kartu keluarga.

Salah satu cara agar pendataan kartu keluarga bisa dilakukan dengan benar, tepat dan cepat adalah dengan adanya program pembenahan dan pendataan ulang pada setiap daerah-daerah, baik itu perkotaan maupun perdesaan. Perlu adanya pendataan pada setiap keluarga, terutama pada kepala keluarga dan seluruh anggota keluarga. Dengan demikian maka rencana pemerintah bisa teratasi dengan tepat. Cara yang dimaksud adalah dengan adanya perancangan sistem pendataan kartu keluarga yang berbasis web.

\section{PERUMUSAN MASALAH}

Sistem Informasi Pendataan Kartu Keluarga Pada Kelurahan Karang Anyar selama ini masih sangat sederhana (manual) yaitu hanya menggunakan microsoft excel lalu dicatat dalam pembukuan yang sederhana. Sering terjadi kesalahan - kesalahan dalam hal ini input data penduduk sehingga sedikit banyak mengganggu kinerja pegawai Kelurahan Karang Anyar. Berdasarkan latar belakang diatas perlu dibangun sistem informasi yang mampu melayani dengan cepat dan tepat.

\section{TINJAUAN PUSTAKA}

\section{Definisi Data}

Sumber informasi adalah data. Data adalah deskripsi tentang benda, kejadian, aktivitas dan transaksi, yang tidak mempunyai makna atau tidak berpengaruh secara langsung kepada pemakai.[1]

\section{Definisi Informasi Informasi Manajemen}

Sistem Informasi Manajemen adalah sebuah sistem informasi yang berfungsi mengelola informasi bagi manajemen organisasi. Peran informasi di dalam organisasi dapat diibaratkan sebagai darah pada tubuh manusia. Tanpa adanya aliran informasi yang sehat, organisasi akan mati. Di dalam organisasi sistem informasi manajemen berfungsi baik untuk pengelolaan transaksi.[2]

\section{Konsep Pemodelan menggunakan Unified Modeling Language}

UML(Unified ModellingLanguage) yang berarti bahasa pemodelan standar. UML bukan hanya sekedar diagram tetapi juga menceritakan konteksnya.UML diaplikasikan untuk maksud tertentu, biasanya antara lain untuk:

1. Merancang perangkat lunak

2. Sarana komunikasi antara perangkat lunak dengan proses bisnis

3. Menjabarkan sistem secara rinci untuk analisa dan mencari apa yang diperlukan sistem 
4. Mendokumentasikan sistem yang ada, proses-proses dan organisasinya

UML telah diaplikasikan dalam bidang investasi perbankan, lembaga kesehatan,sistem terdistribusi, sistem pendukung, alat kerja, retaildan lain-lain.

Blok pembangunan utama UML adalah diagram. Beberapa diagram ada yang rinci (jenis timing diagram) dan lainnya ada yang bersifat umum (misalnya diagram kelas).Para pengembang sistem berorientasi objek menggunakan bahasa model untuk menggambarkan, membangun dan mendokumentasikan sistem yang mereka rancang. [3]

\section{Definisi Aplikasi}

Aplikasi merupakan program yang dikembangkan untuk memenuhi kebutuhan pengguna dalam menjalankan pekerjaan tertentu.[4]

\section{METODOLOGI PENELITIAN}

Dalam mendapatkan data pada penelitian ini digunakan beberapa metode yaitu :

\section{Metode Pengumpulan Data}

1. Metode Observasi

Melakukan tinjauan secara langsung ke Kelurahan Karang Anyar yang terletak di Jl. Nyi Mas Melati No. 01 Rt. 002/02. Kecamatan Neglasari provinsi Banten dengan kode pos 15121. Untuk menghasilkan data-data yang dibutuhkan dilkakuan pengamatan dan menggunakan pencatatan sistematis kepada unsur yang diteliti.

2. Metode Interview (wawancara)

Dalam mengumpulan data-data yang diperlukan untuk penelitian, penulis melakukan wawancara secara lisan kepada Bapak Nur Alamsyah selaku stake holder dengan jabatan sebagai staff pegawai diKelurahan Karang Anyar.

3. Metode Pustaka

Pengumpulan data dengan mempelajari buku-buku dan kasus yang serupa dengan judul yang diangkat.

\section{Metode Analisis}

Dalam metode analisis sistem dilakukan melalui 4 tahap, yaitu:

1. Surveyterhadap sistem yang sedang berjalan.

2. Analisis terhadap temuan survey.

3. Indentifikasi temuan survey.

4. Indentifikasi persyaratan sistem.

Hasil analisa kemudian dibuat laporan untuk masukan dalam perancangan sistem yang diusulkan.

\section{LITERATURE REVIEW}

1. Penelitian yang dilakukan oleh Mochamad Taufik pada tahun 2009 dengan judul "Pengembangan Sistem Informasi Pendataan Penduduk Tingkat Desa". Penelitian ini membahas mengenai rancangan suatu sistem informasi kependudukan. Sistem informasi pendataan penduduk pada tingkat desa ini sangat membantu instansi pemerintah dalam pendataan penduduk dalam ruang lingkup sebuah desa. Dimana sistem ini melakukan proses pendataan seiring dengan proses pengajuan surat-surat kependudukan oleh setiap penduduk yang datang ke kantor kepala desa. Dengan demikian data kependudukan dapat diperoleh dengan mudah tanpa harus melakukan pendataan secara langsung ke tempat penduduk tersebut tinggal.[5]

2. Penelitian yang dilakukan oleh Rachel Kurniawati pada tahun 2016 dengan judul"Pengembangan Sistem Informasi Kependudukan Berbasis MobileDanRestful Web Service”. Penelitian ini 
membahas mengenai penerapanREST web service yang mengintegrasikan data dari database SQLite ke database server MySQL dan sangat membantu proses pengumpulan datapenduduk.Akan sangat efektif dan efisien waktu dan biaya. Dapat menekan biaya cetak kertas yang disebar kependudukdan ongkos tenaga petugas sensus, ditambah lagi meskipun sangat minim koneksi internet proses sinkronisasi tetap dapat dilakukan.[6]

3. Penelitian yang dilakukan oleh Usman Ependi pada tahun 2012 dengan judul "Sistem Informasi Pemetaan Data Penduduk Miskin Di Kabupaten Ogan Komering Ulu Sumatera Selatan”. Penelitian ini membahas mengenai Sistem informasi pemetaan data penduduk yang ada pada kabupaten Ogan Komering Ulu yang berstatus sejahtera, menengah, hampir miskin, miskin dan sangat miskin. Informasi didapat melalui proses yang dijalankan oleh sistem informasi pemetaan data penduduk miskin berdasarkan format form pendataan penduduk miskin Badan Pusat Statistik (BPS) provinsi Sumatera Selatan pada tahun 2008 dan 2011.[7]

4. Penelitian yang dilakukan oleh Fiftin Noviyanto pada tahun 2014 dengan judul” Implementasi Sikades (Sistem Informasi Kependudukan Desa) Untuk Kemudahan Layanan Administrasi Desa Berbasis Web Mobile”. Penelitian ini membahas mengenaiSistem Informasi Kependudukan Desa (SIKADES) di Kecamatan Samigaluh yang melibatkan 2 Desa dan 4 kelurahan. Pengguna sistem ini meliputi: Camat, Lurah, Dukuh dan Warga. Penelitian ini berhasil mengimplementasikan SIKADES (Sistem Informasi Kependudukan Desa) yang memanfaatkan teknologi Web Mobile, untuk kemudahan layanan.Berdasarkan pengujian sistem serta pelatihan yang dilaksanakan sistem ini telah layak dikembangkan dan memungkinkan pengembangan untuk daerah lain.[8]

5. Penelitian yang dilakukan oleh Karnadi pada tahun 2014 dengan judul” Aplikasi Pelayanan Sistem Informasi Pengolahan Data Penduduk Pada Kelurahan 7 Ulu Palembang Dengan Borland Delphi 7.0”. Penelitian ini membahas mengenaiaplikasi pengolahan data-data masyarakat pada kelurahan 7 Ulu Palembang sehinggadapat melayani masyarakat dengan cepat dan akurat baik perpindahan, domisili, dan surat-surat dalam bentuk keterangan yang dibutuhkan oleh masyarakat pada pada kelurahan 7 Ulu Palembang. Dasar dari program aplikasi ini yaitu bahasa pemrograman Borland Delphi 7.0 dan salah satu aplikasi untuk mendukung pembuatan aplikasi ini yaitu aplikasi MySQL. Dari hasil analisa penulisan ini dengan aplikasi perangkat lunak ini, menunjukan bahwa aplikasi ini sangat menunjang dalam proses pelayanan masyarakat, dan aplikasi ini juga mempunyai keamanan (security) berupa password yang apabila ingin menjalankan aplikasi ini, didahului dengan Login, dan aplikasi ini juga dapat digunakan dengan mudah.[9]

Dari 5 literature review yang ada dapat ditarik kesimpulan bahwa pendataan kartu penduduk bisa diimplementasikan dengan menggunakan bahasa pemrograman komputer. Bahasa pemrograman yang dipakai bisa menggunakan Web Mobile dan juga pemrograman berbasi desktop yaitu Borland Delphi.

\section{PEMECAHAN MASALAH}

Perancangan Sistem

Dalam perancangan Aplikasi jenjang sosial pendataan kartu keluarga melalui web ini menggunakan program Visual Paradigma for UML 4.0. Unified Modelling Language (UML) merupakan metode pengembangan perangkat lunak (sistem informasi) dengan menggunakan metode grafis serta merupakan bahasa untuk visualisasi, spesifikasi, konstruksi serta dokumentasi. 


\section{Use case diagram}

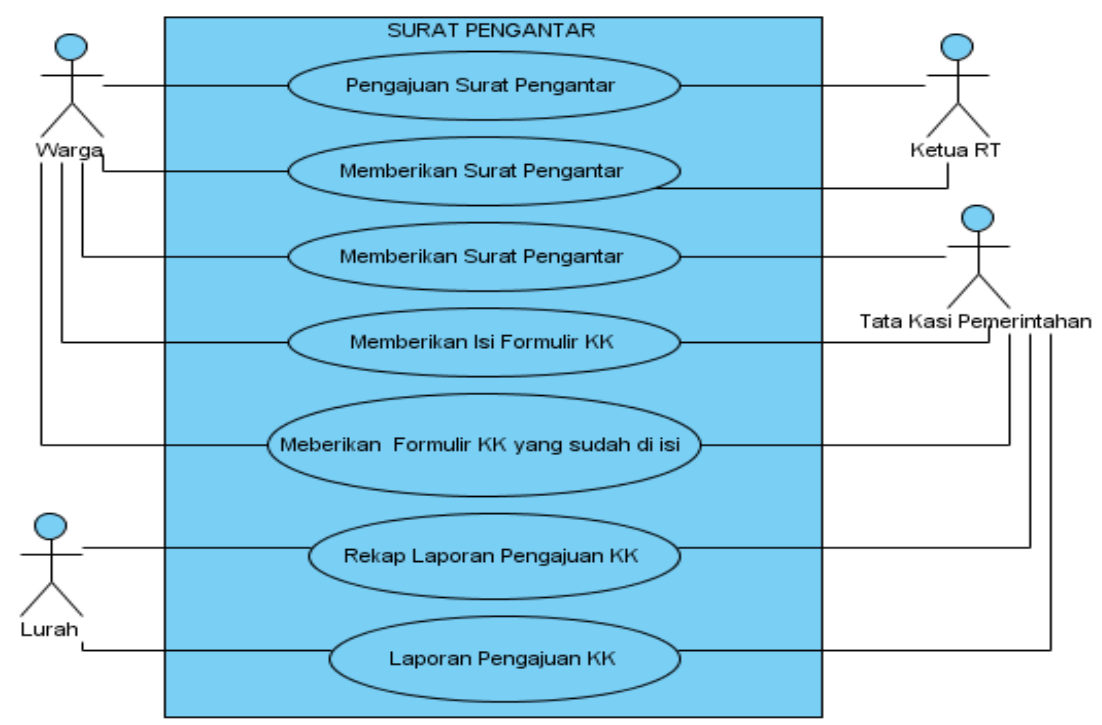

Gambar 1. Use Case Diagram

Didalam Use Case diagram ini, terdapat :

1. 4 actor yang melakukan kegiatandiantaranya : Warga, Ketua RT, Tata Kasi Pemerintahan dan Lurah.

2. 7 Use Case yang dapat dilakukan oleh actor tersebut, yaitu : use case pengajuan surat pengantar, memberikan surat pengantar, memberikan isi formulir KK, memberikan formulir KK yang sudah di isi, rekap laporan pengajuaan KK, Laporan Pengajuan KK.

3. 1 sytem yang mencakup seluruh kegiatan pengajuan pembuatan kartu keluarga.

\section{Class diagram}

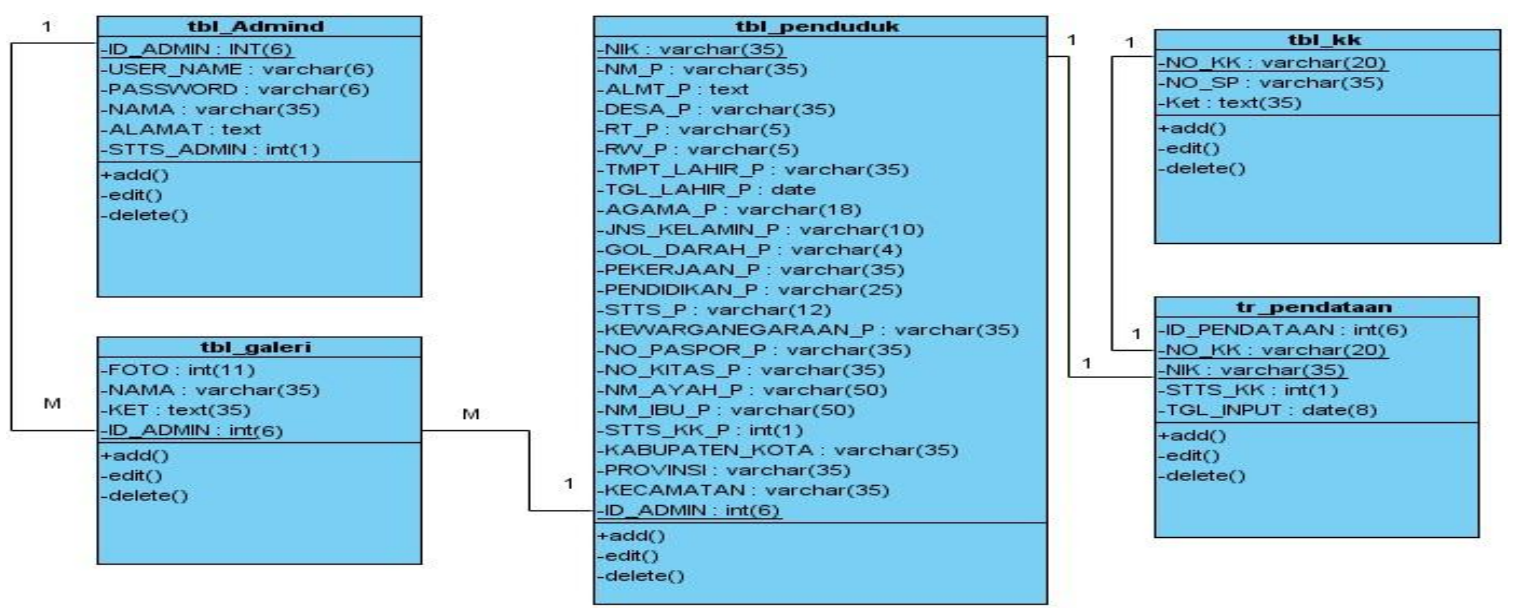

Gambar 2. Class Diagram yang diusulkan

Didalam Classdiagram ini, terdapat :

1. 5 Class, himpunan dari objek-objek yang berbagi atribut serta operasi yang sama.

2. 4 Association, hubungan antara objek satu dengan objek lainnya yang mempunyai nilai 
Sequence Diagram Login pada Kelurahan Karang Anyar

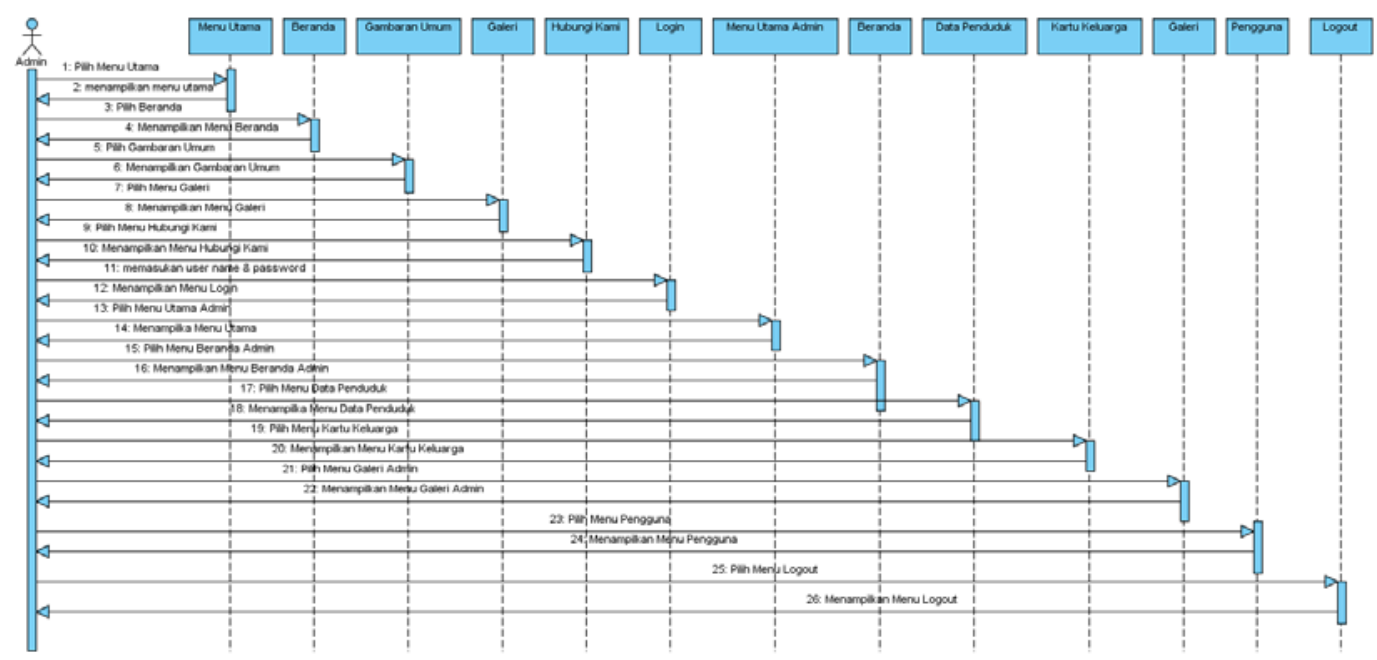

Gambar 3. Sequence Diagram Login

Berdasarkan Gambar 3. Sequence Diagram Login yang diusulkan terdapat :

a. 13 Lifeline antarmuka yang saling berinteraksi.

b. 1Actor yang melakukan kegiatan, yaitu user admin.

c. 26 message spesifikasi dari komunikasi antar objek yang memuat informasi-informasi tentang aktifitas yang terjadi.kegiatan yang biasa dilakukan oleh actor-actor.

Statechart Diagram untuk Admin

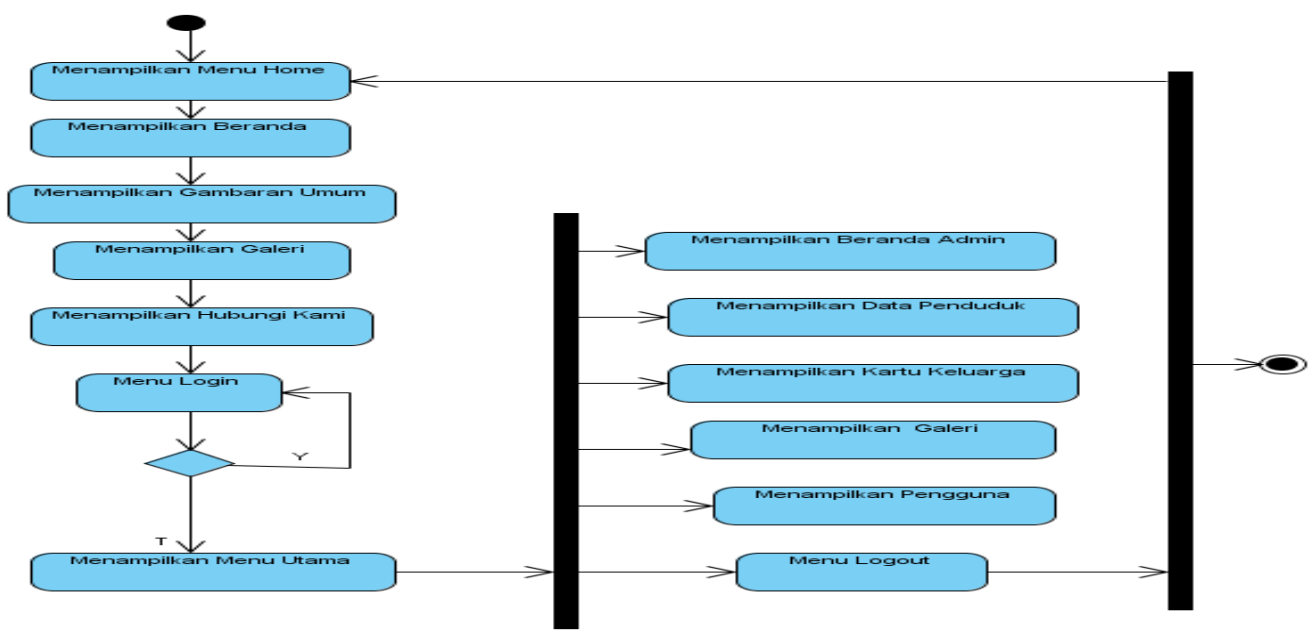

Gambar 4. State Chart Diagram untuk admin

Berdasarkan Gambar 4. State ChartDiagram yang diusulkan terdapat :

a. 1 Initial Pseudo State, objek yang diawali

b. 13 State, nilai atribut dan nilai link pada suatu waktu tertentu, yang dimiliki oleh suatu objek tersebut.

c. 1 Decision Node, untuk membuat keputusan.

d. 2 Fork Node, satu aliran yang pada tahap tertentu berubah menjadi beberapa aliran

e. 1 Final state, objek yang diakhiri.4.2.4. Analisa Sistem Yang Diusulkan Pada Class Diagram. 


\section{Rancangan Implementasi}

\section{Tampilan Program}

\section{Tampilan Halaman Beranda}

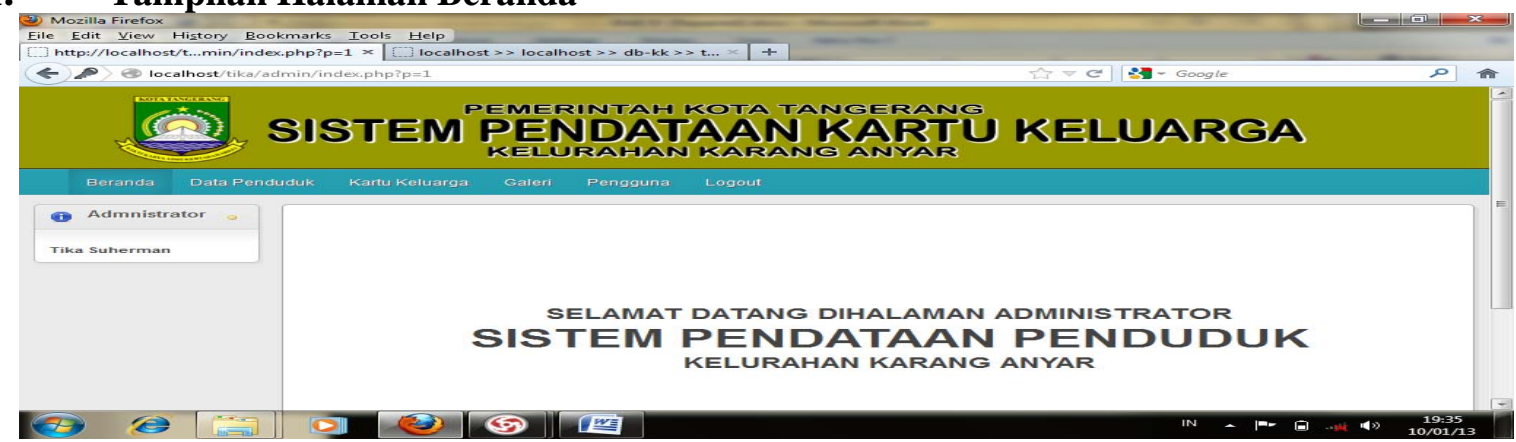

Gambar 5. Tampilan Menu Halaman Beranda

Tampilan beranda ini adalah tampilan awal program dan menu login. Pada tampilan beranda ini terdapat beberapa menu yaitu, data penduduk, kartu keluarga, galeri, pengguna dan logout.

Keterangan mengenai masing-masing menu pada tampilan home :

a. Data penduduk, tampilan ini berisi mengenai proses penduduk pendatang baru yang ingin membuat kartu keluarga d kelurahan karang anyar.

b. Kartu keluarga, tampilan ini berisi mengenai proses pembuatan kartu keluarga, penduduk yang sudah memegang surat pengantar dari RT langsung lapor dan membuat kartu keluarga.

c. Galeri, tampilan ini berisi mengenai kegiatan - kegiatan di kelurahan karang anyar.

d. Pengguna, tampilan ini berisi mengenai proses pengguna admin yang melakukan proses penginputan data.untuk pembuatan kartu keluarga baru maupun perubahan kartu keluarga.

e. Logout, tampilan ini untuk keluar dari system

\section{Tampilan Halaman Data Penduduk}

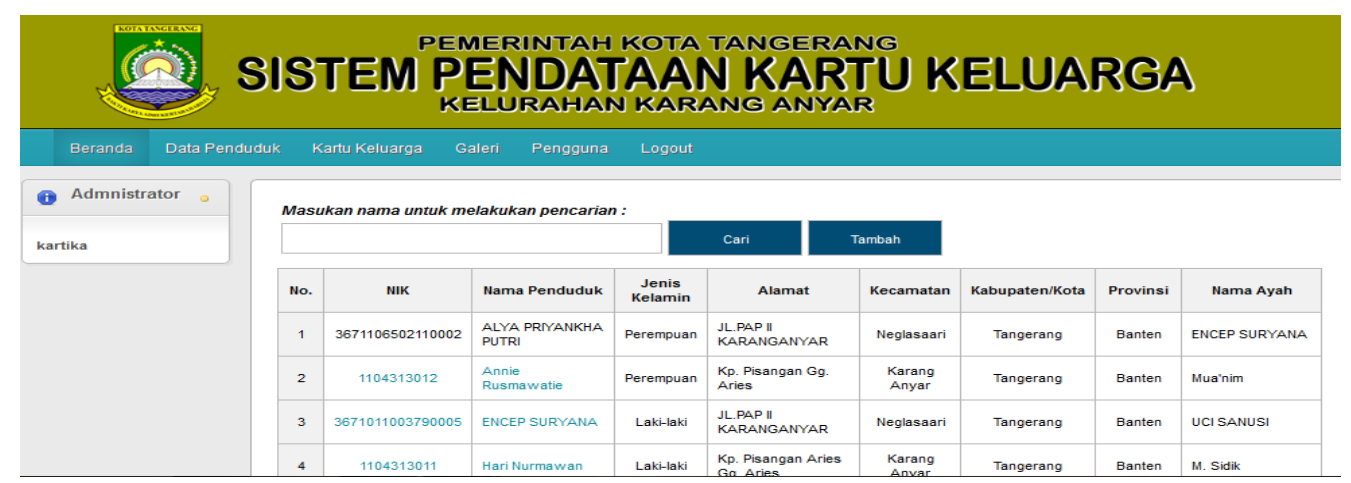

Gambar 6. Tampilan Menu Halaman Data Penduduk

Tampilan data penduduk ini berisi mengenai pencarian nama penduduk yang sudah di input namanya untuk mengerjakan proses pembuatan kartu keluarga. Data penduduk yang ditampilkan itu terdiri dari NIK (Nomer Induk penduduk), nama penduduk, jenis kelamin, alamat, kecamatan, kabupaten/kota, provinsi dan nama ayah. 


\section{Tampilan Halaman Menu kartu keluarga}

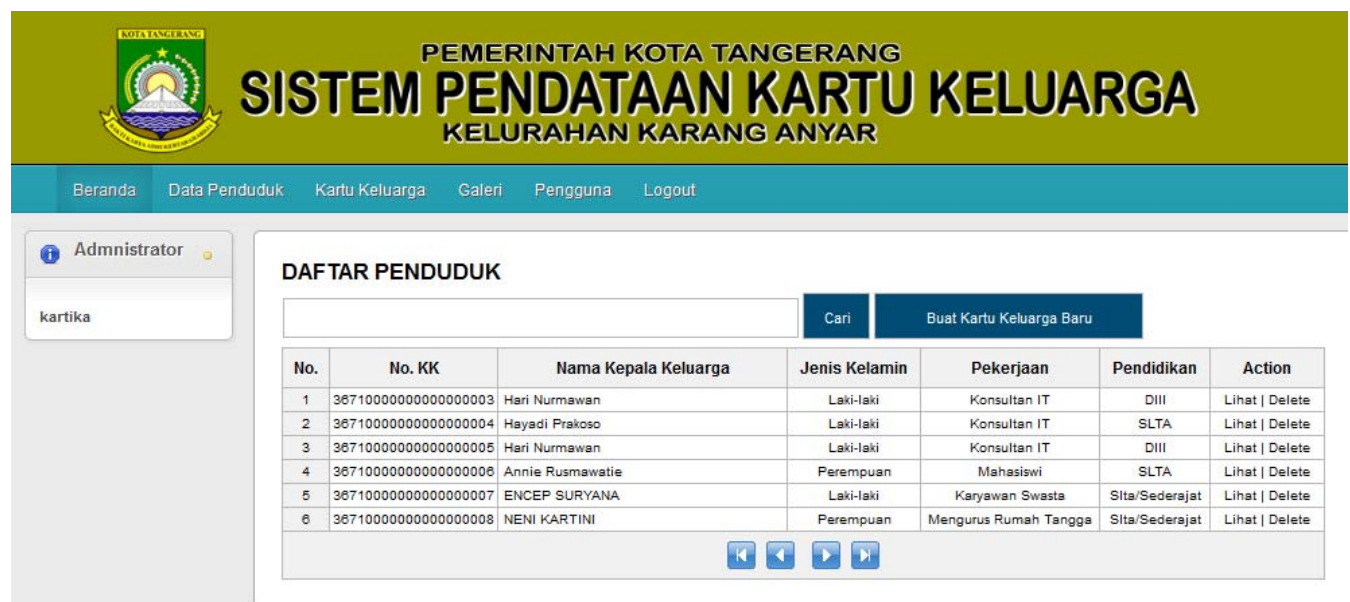

Gambar 7. Tampilan Menu kartu penduduk

Tampilan ini berisi tentang input daftar penduduk untuk melanjutkan proses pembuatan kartu keluarga baru. Field yang harus dimasukkan kedalam menu ini adalah no kartu keluarga, nama kepala keluarga, jenis kelamin, pekerjaan dan pendidikan. Dalam menu ini juga dapat dilihat hadil inputan dan jika ada kesalahan bisa melakukan penghapusan.

\section{Tampilan Halaman Kartu Keluarga}

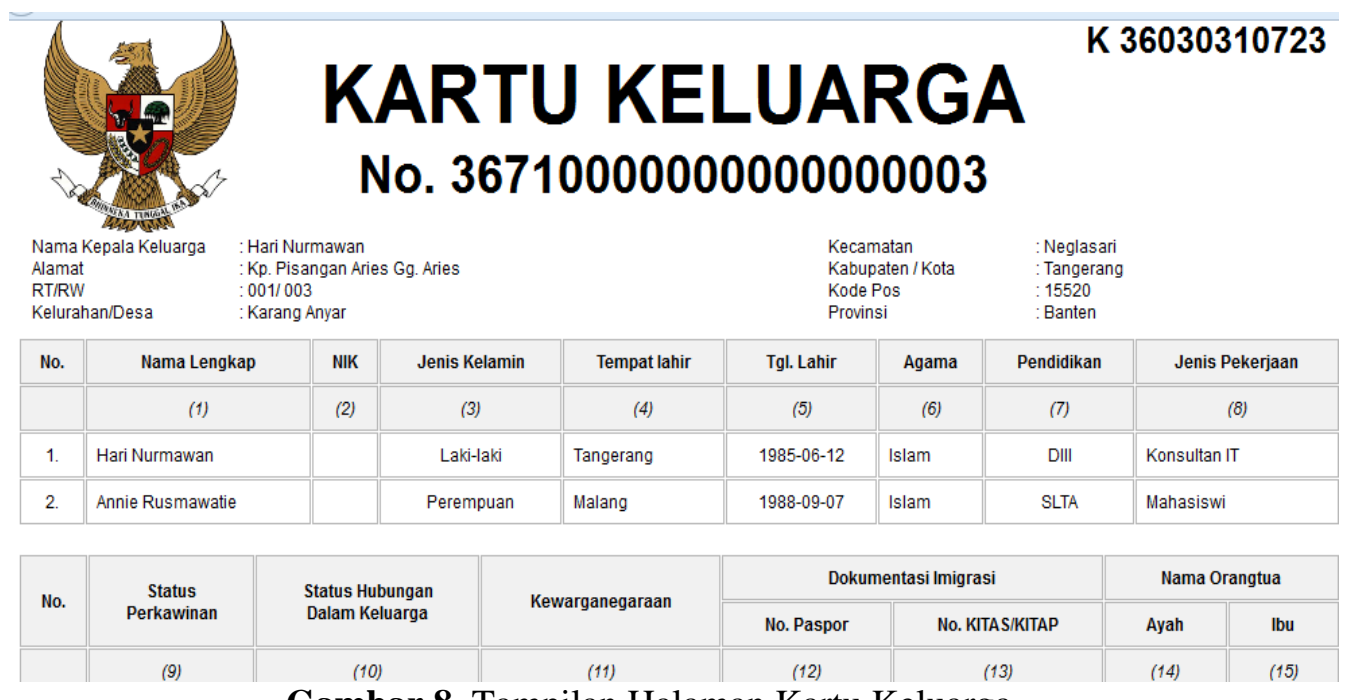

Gambar 8. Tampilan Halaman Kartu Keluarga

Tampilan ini berisi kartu keluarga yang siap di cetak setelah hasil pemprosesan penginputan data penduduk. Menu kartu keluarga ini terdiri dari nama kepala keluarga, alamat, RT/RW, Kelurahan/Desa, Kecamatan, Kabupaten/Kota, kode pos, provinsi, nama lengkap, nomer induk kependudukan (NIK), jenis kelamin, tempat lahir, tanggal lahir, agama, pendidikan dan jenis pekerjaan.

\section{KESIMPULAN}

Setelah dianalisis pada sistem Pendataan Kartu Keluarga dapat dilihat mengenai prosedur-prosedur dalam sistem pembuatan kartu keluarga yang berjalan saat ini masih bersifat manual dan konvensional. Pada perancangan sistem pendataan kartu keluarga yang diusulkan, dihasilkan sebuah program yang dapat memberikan efektifitas dan efisiensi secara optimal terhadap jalannya proses 
prosedur. Aplikasi Sistem Pendataan Kartu Keluarga Pada Kelurahan Karang Anyar ini dapat membantu permasalahan yang dihadapi di Kelurahan Karang Anyar khususnya tentang laporan data pembuatan kartu keluarga sehingga memudahkan admin dalam penginputan data laporan secara cepat dan akurat.

\section{DAFTAR PUSTAKA}

[1] Kodir, Abdul.“Pengenalan sistem informasi”. Yogyakarta:Andi, 2003.

[2] Nugroho, Eko "Sistem informasi manajemen”. Yogyakarta:Andi. 2008

[3] Widodo, Pudjo, Prabowo "Menggunakan UML”. Bandung: Informatika. 2011

[4] Yuhefizar. "Menguasai Internet Teknologi dan Aplikasi”. Jakarta : PT Elex Media Komputindo, 2011.

[5] Taufik, Mochamad, Dedy Prastyo, Suparno. 2009. Pengembangan Sistem Informasi Data Kependudukan Tingkat Desa. SNTI. Semarang : Universitas Islam Sultan Agung.

[6] Kurniawati, Rachel. 2016. Pengembangan Sistem Informasi Kependudukan Berbasis Mobile Dan Restful Web Service. SENTIKA. Yogyakarta : Universitas Atma Jaya.

[7] Ependi, Usman. 2012. Sistem Informasi Pemetaan Data Penduduk Miskin Di Kabupaten Ogan Komering Ulu Sumatera Selatan. DIGITAL INFORMATION \& SYSTEM CONFERENCE. Palembang: Universitras Bina Darma.

[8] Noviyanto, Fiftin, Setiadi, tedy, Wahyuningsih, Iis. 2014. "Implementasi Sikades (Sistem Informasi Kependudukan Desa) Untuk Kemudahan Layanan Administrasi Desa Berbasis Web Mobile. Jurnal Informatika. Yogyakarta: Universitas Ahmad Dahlan. Vol. 8, No. 1, Januari 2014.

[9] Karnadi. 2014. “Aplikasi Pelayanan Sistem Informasi Pengolahan Data Penduduk Pada Kelurahan 7 Ulu Palembang Dengan Borland Delphi 7.0”. Jurnal Sigmata. Palembang: AMIK Sigma. Volume 2 : Nomor : 2 Edisi : April 2014 - September 2014. 